\title{
Contemplación artística y escucha analítica. A propósito de Velázquez, pájaro solitario, de Ramón Gaya
}

\section{Artistic Contemplation and Analytical Listening. Regarding Ramon Gaya’s Velázquez Solitary Bird}

\author{
Eduardo CHAMORRO ROMERO \\ Universidad Complutense de Madrid \\ eduardochamorro@telefonica.net
}

Recibido: 23 de noviembre de 2010

Aceptado: 24 de noviembre de 2010

"Una concavidad de silencio. En un momento he podido creer que eso era el arte. (Y lo es, en definitiva), pero una concavidad de silencio es en realidad lo vivo. El arte, si es vivo, participa de esa condición."

Ramón Gaya. Anotaciones de diario inéditas. La Serenísima, 25 de mayo de 1958.1

\section{Resumen}

Una concavidad de silencio... eso es el arte". El artículo toma como hilo conductor esta cita de Ramón Gaya, para ir recorriendo sus textos y sintetizar lo esencial de su experiencia del arte o, como él solía expresar, su creencia en el arte. Creencia que inunda tanto su faceta de contemplador como de creador.

Se analiza su escritura, tendente a crear un clima peculiar de escucha entre escritor y lector, y se confronta con la "escucha analítica". Por último, se esboza lo que constituiría el itinerario de Ramón Gaya en la construcción de su pensamiento

\footnotetext{
${ }^{1}$ Gaya, R., Obras completas, Vol. 1, Valencia, Pre-textos, 2010, p. 579.
} 
sobre el arte. Más allá de una "teoría del arte" se trata de una quête que tiene como fin la transformación de la propia subjetividad.

Palabras clave: Metáfora, concavidad, borradura, represión, silencio, vacío, belleza, regazo materno, crear, lo vivo.

\begin{abstract}
'A hollow of silence... that is art'. The present article takes this quotation by Ramón Gaya as a guiding thread to go over his texts and to summarize the essentials of his art experience or, as he used to put it, his belief in art. This belief inundates not only his facet as beholder but also his as author.

Tending to create an unusual listening atmosphere between writer and reader, his writing is analysed and compared with the 'analytical listening'. Finally, it is outlined what it would constitute the itinerary on the construction of Gaya's thoughts about art. Beyond being an "art theory', it is about a quête aimed to transform one's own subjectivity.
\end{abstract}

Keywords: Metaphor, concavity, erasure, repression, silence, emptiness, beauty, mother's lap, to create, the alive.

He escogido esta cita, tan sugerente, de Ramón Gaya porque estimo que condensa lo esencial de su pensamiento sobre el arte. Y porque narra, con gran sencillez, cómo ha sido su búsqueda -azarosa, difícil, titubeante- en pos de la esencia del arte. Pensar el arte, penetrar en su esencia, de la única manera posible: a través de una intensa experiencia del arte - del "arte verdadero", como él suele precisar-y que identifica con la creencia en el arte. Creencia que inunda tanto su faceta de contemplador como de creador. Llegar a ello, nos dirá, significa emprender un camino cuyo primer paso consistirá en desprenderse de todos los prejuicios y dejar que la obra de arte nos hable... Es lo que hemos intentado hacer con sus textos. Al hacerlo -tanto si se trata de un ensayo, de unas anotaciones de viaje, o de una carta-, no encontraremos en ellos pensamientos terminados, cristalizados, sino la voz de alguien que está construyendo su propio decir sobre el arte, en un tono conversacional, que parece llevarnos de la mano hacia algún lugar en donde se difuminaran los perfiles de autor y lector, como si desaparecieran, y el texto siguiera ahí, gestándose, naciendo e impregnando nuestra mente, nuestros sentidos... Escritura auroral, podríamos decir.

Pero, más allá de ésta su intencionalidad -el transmitirnos RG su creencia en el arte-, en la lectura atenta de sus textos es posible rastrear cómo ha ido construyén- 
dose un "universo simbólico" propio, para cuyo análisis la imagen de la "concavidad" - que podríamos calificar de "imagen matriz"- nos servirá de hilo conductor, y nos llevará a la descripción de los que podemos llamar "espacios de la subjetividad". Esbozar, en lo posible, ese universo simbólico es el objetivo de este artículo.

Intentaremos conjugar una doble perspectiva de lectura: la fenomenológica, que tiene como finalidad explícita la comprensión del texto, y la psicoanalítica, que introduce en la lectura una específica modalidad de escucha -próxima a la que el analista pone en acto en la sesión analítica- y que tiene en cuenta la "superficie del texto", su literalidad, estilo, repeticiones, "desvíos", imágenes... Se trata de una continua pregunta que no busca, como en la perspectiva fenomenológica, qué dijo -o, incluso, qué quiso decir- el autor del texto, sino, qué se está produciendo ahora, en el tiempo de la lectura, qué texto "resulta", qué dimensiones adquiere en esta disposición de escucha... Doble perspectiva que, en el caso de los textos de Gaya, pareciera desprenderse de ellos mismos. Pues encontramos en ellos el esmero propio del fenomenólogo, un cuidado especial por encontrar la palabra adecuada en cada momento para expresar tanto sus impresiones sobre una obra de arte, sobre una ciudad o sobre una persona, como los conceptos con los que construir un razonamiento. De ahí el uso en cadena de adjetivos con los que sus frases van acumulando matices. O los puntos suspensivos con los que dice de la imposibilidad de seguir precisando más... Y, respecto a la perspectiva psicoanalítica, llama la atención la mirada crítica continua sobre la realidad exterior confrontada siempre con su propio sentir. ${ }^{2}$

2 A partir del artículo de Lacan "El tiempo lógico y el aserto de certidumbre anticipada. Un nuevo
sofisma", (1966/1971, pp. 21-36) podrían esbozarse los lineamientos de un método interpretativo. En
él cobra especial importancia ese instante en el que nos sentimos conmovidos por el impacto que nos
provoca el texto o alguno de sus elementos. Es el instante de la mirada. Si ese instante privilegiado
sigue trabajándonos, vendrá luego un tiempo de comprender en el que nos preguntamos qué pudo ser
aquello que se suscitó en nosotros en ese instante, por qué nos impactaría tal palabra, tal escena, tal
frase ... El ir tanteando posibles respuestas, el ir buscándolas de acá para allá, en actitud de "atención
flotante" hacia el texto, en un trabajo de análisis de los mecanismos de condensación y desplazamien-
to que están actuando en nosotros, es lo que caracteriza la crítica textual de inspiración psicoanalítica.
Equivalente al trabajo de interpretación de los sueños que instaura Freud frente a otros métodos de her-
menéutica onírica. El material que trabajamos, como el del sueño, es trasladado a un espacio asocia-
tivo en el que la pregunta "qué significa este texto", se nos presenta como pantalla que oculta y des-
vela otra pregunta: "qué me pasó que me sentí concernido". Pregunta ésta que aparece con tal fuerza
que no permite escapatoria. Sólo en la medida en que vamos dando respuestas a esta pregunta algo de
la anterior, la pregunta por el significado, puede desvelarse. Pues bien, este trabajo de hallazgo de aso-
ciaciones y de afectos que van surgiendo -yo no busco, encuentro, decía Picasso- con fluidez en oca-
siones, con resistencia en otras, encuentra un limite que se me impone... Es el momento de concluir.
Resumo: Instante de la mirada, tiempo de comprender, momento de concluir marcan no los hitos de 
Comenta Andrés Trapiello 3 en el Prólogo a la Antología de los escritos de RG: "Y, como raras veces ocurre cuando se abordan tales cuestiones, es decir, mientras hablaba del acto mismo de creación, nos ha dado Ramón Gaya en estos escritos algo que en sí mismo es la expresión cumplida de eso de lo que él viene tratando, es decir, una verdadera obra creada, nacida, arrancada suavemente a su tembloroso pensar, a su firme sentir, algo, en fin, que nos resulta más que deslumbrante (y en ocasiones lo es), luminoso, es decir, con luz propia, de dentro afuera".

Tembloroso pensar, firme sentir. Y también lo contrario, tembloroso sentir, firme pensar. Afecto y pensamiento, firmeza y temblor entrelazados. Y de esa íntima unión nace esa luz que ilumina la escritura y la pintura de Ramón Gaya. Es entre 1945 y 1968 el periodo en el que va escribiendo los que considero sus textos fundamentales sobre el arte. Podemos pensar que en esos años -recordemos, largos años de exilio- trabaja con notas tomadas desde hacía mucho tiempo, desde aquella su madura adolescencia en contacto con los grandes literatos y artistas de su época, notas en las que habría ido reflejando sus apreciaciones acerca del arte, al tiempo que investigaba también -y sobre todo-con sus propias manos, en su intensa dedicación a la pintura. A partir de esas notas, escritas muchas veces en condiciones tan adversas, iría escribiendo los textos que serían publicados más tarde.

Menciono los que considero más importantes: El "Homenaje a Velázquez", de 1945, "El silencio del arte", de 1951, "El sentimiento de la pintura", de 1959, "Velázquez, pájaro solitario" con las "Anotaciones" y "Otras anotaciones", entre 1961 y 1968 y "Naturalidad del arte (y artificialidad de la crítica)", de 1975 a 1996-, todos ellos referidos a la pintura y, especialmente, a la de Velázquez.

\section{1. "Una concavidad de silencio"}

Por más familiaridad que tengamos con el lenguaje poético, al escuchar esta expresión -"una concavidad de silencio"- nos sentimos desconcertados, pues una concavidad es algo que se nos presenta en el espacio tridimensional y, por tanto, que podemos representarnos fácilmente a partir de las cualidades que están asociadas a los sentidos de la vista y el tacto, pero difícilmente al sentido del oído. Pues sólo decir "concavidad" y nuestra mente, a partir de los significados y las resonancias que las palabras llevan en sí mismas, despliega automáticamente ante nosotros imágenes visuales y táctiles. Decir "concavidad" es evocar espacios, preferentemente

una secuencia interpretativa a recorrer, sino los tiempos lógicos que se entrecruzan continuamente, arrastrados por el pathos, en diversas direcciones hacia algún saber concreto, un saber que aparece como límite, que marca el límite de ese impulso, y, así, lo apacigua: un logos enunciable que posibilita un cierre a la interpretación, y cierre que, a su vez, volverá a convertirse en nueva apertura, nuevo rasgado, nuevo instante de la mirada, nuevo tiempo de comprender, nuevo momento de concluir...

3 Trapiello, A. Del pintar. Trazado de desnudo. http://www.cervantesvirtual.com. p.190. 
grandes, que uno contempla y cuyo contorno podemos observar o imaginar. Así, por ejemplo, el abismo, la sima, la cueva, el pozo, la laguna, el mar... vienen a nuestra mente cuando intentamos dar concreción al término abstracto "concavidad". Y, a partir de las experiencias que hayamos vivido en relación con esos espacios, se despertarán en nosotros unos sentimientos u otros. Algunas, la del abismo, la cueva, el pozo, la laguna sin fondo o el mar vienen asociadas a lo inquietante, lo siniestro, lo peligroso...

¿Podríamos incluir en este listado los sentimientos que nos suscita la visión del cielo cuando lo contemplamos, al modo de Fray Luis, "alejados del mundanal ruido"? ¿No es, quizá, el denominado por Romain Rolland "sentimiento oceánico", - ese sentimiento de infinitud que estaría, según este autor, en la base de todas las manifestaciones de la religiosidad-y al que dedicó Freud el primer capítulo de $E l$ malestar en la cultura? 4 Es probable que la expresión "bóveda del cielo" -con la que decimos estrictamente lo que vemos - una concavidad- se haya acuñado en el lenguaje precisamente porque amortigua la inquietud que suscita lo que sabemos, y lo que ignoramos, acerca de lo que hay detrás de esa bóveda...

"Una concavidad de silencio". Se trata, es claro, de una metáfora en la que se articulan dos significantes, a través de la preposición $d e .{ }^{5}$ Un poco más adelante, en

\begin{abstract}
4 Freud (1930/2001, pp. 65-73) cita literalmente a su amigo Romain Rolland para expresar qué entiende éste por "sentimiento oceánico": "Es - me decía- un sentimiento particular que a él mismo no suele abandonarlo nunca, que le ha sido confirmado por muchos otros y se cree autorizado a suponerlo en millones de seres humanos. Un sentimiento que preferiría llamar sensación de "eternidad"; un sentimiento como de algo sin límites, sin barreras, por así decir, "oceánico." Este sentimiento -proseguía- es un hecho puramente subjetivo, no un artículo de fe; de él no emana ninguna promesa de pervivencia personal, pero es la fuente de la energía religiosa que las diversas iglesias y sistemas de religión captan, orientan por determinados canales y, sin duda, también agotan. Sólo sobre la base de ese sentimiento oceánico es lícito llamarse religioso, aun cuando uno desautorice toda fe y toda ilusión". Freud reconoce no haber experimentado nunca tal sentimiento. "Yo no puedo descubrir en mí mismo ese sentimiento oceánico". A partir de aquí, pues, sin referencia posible a la propia experiencia, cree que "no le queda otro recurso que atenerse al contenido de representación que mejor aparece asociativamente con tal sentimiento". El contenido representacional tiene, para Freud, el carácter de una "visión intelectual" con cierto "tono afectivo". Lo expresa en estos términos: "atadura indisoluble", "copertenencia con el todo del mundo exterior", "Ser-Uno con el Todo", "ilimitación y atadura con el Todo". Freud, pues, no intenta someter a análisis esa experiencia, sino lo que él estima que es el contenido representacional más afin a tal expresión. Y es, por tanto, este contenido representacional el que será interpretado como expresión (adulta) de un estrato infantil que perdura en el psiquismo al modo como, en el desarrollo de las ciudades - y significativamente Freud escoge como ejemplo la ciudad de Roma-ciertos restos de la arquitectura perteneciente a las etapas primeras de la construcción se conservan a lo largo de las sucesivas transformaciones que se han ido realizando posteriormente. El "sentimiento oceánico" remite, pues, a un estadio de la evolución infantil: aquél en el que el "lactante no separa todavía su yo de un mundo exterior como fuente de las sensaciones que le afluyen." El yo es un puro yo-placer "con tendencia a segregar de sí todo lo que pueda devenir fuente de un tal displacer, a arrojarlos hacia fuera, a formar un yo-placer al que se contrapone un ahí-afuera ajeno, amenazador" (p. 68)

5 Esta vinculación por medio de la preposición "de" dificilmente escapa a cierta ambigüedad. Así, por ejemplo, si decimos "el deseo de la madre" podemos referimos al deseo del hijo hacia su madre o al deseo de ésta. Cuando no es posible especificar quién es el sujeto de la acción -si el deseante es el hijo o la madre-es necesario recurrir al contexto de la frase. El psicoanalista que escuchara a su paciente hablar del "deseo de la madre", en el contexto de la sesión ana-
\end{abstract}


la misma frase, la metáfora se amplía y forma parte de una proposición afirmativa. RG dirá que esa "concavidad de silencio", "eso es el arte".

En Retales de un diario, Barcelona, 31 de octubre de 1960, nos dice RG (OC, p. 494): "La metáfora no quiere, en absoluto, caracterizar, expresar, y claro, mucho menos aún, adornar la realidad, sino borrar en ésta todo lo externo, lo aparente, y que pueda surgir entonces, ya sin trabas, lo suyo más recóndito".

Esta concepción de la metáfora es muy cercana a la psicoanalítica. No caracterizar, no expresar, no adornar, sino, sobre todo, borrar. Cuando RG dice "borrar todo lo externo, lo aparente", podemos añadir: borrar incluso el significado habitual que tiene cada uno de los significantes con los que está construida la metáfora -en nuestro caso, los significados habituales que damos a los términos "concavidad" y "silencio" y teniendo en cuenta que esta operación de borrado tiene un alcance tal que no llega sino muy parcialmente a la conciencia del creador, pues aunque éste pueda considerarse, con toda razón, autor, el trabajo lo realiza en realidad... el mismo lenguaje. Se trata de un trabajo -el denominado "trabajo de la metáfora"-, efecto de la represión y, por tanto, fundamentalmente inconsciente 6 . De ahí que ciertas expresiones, tan frecuentes en los grandes creadores -"el lenguaje nos habla" o, recuérdese a Chillida, "escucho lo que me dice el hierro en la fragua"-, son profundamente verdaderas. Un significante, decíamos, es borrado por la acción de otro significante $-y$ un significante puede ser todo el universo simbólico de un poeta-, si bien, el significante rechazado no desaparecerá del todo. Vuelve, transformado, desde esa zona a la que ha sido arrojado, trayéndonos algo, "lo suyo más recóndito", que estaba latente en él, pero que no había podido arrancársele sino por la presencia de ese otro significante. Ese estar continuamente sobre el lenguaje, despojándolo de significados familiares, es, justamente, el trabajo de la metáfora. Ello hace posible que las palabras vuelvan otra vez a nosotros, vuelvan a nacer, pero ya con significados nuevos...

Refiriéndonos a la expresión "una concavidad de silencio", podríamos decir: se trata de una determinación en la que uno de los sustantivos, "silencio", califica metafóricamente a otro, "concavidad", calificación que no es del orden de lo visualtáctil, sino del orden de lo sonoro, o, mejor, de la ausencia de lo sonoro, y es el silencio. Pero ahí hemos dado el salto a lo metafórico. (No sería así si dijéramos "una concavidad azul", pues, en este caso, nos mantenemos en el orden de lo visual-tác-

lítica, y se quedara con la duda acerca de lo que ha escuchado - si el paciente se está refiriendo al deseo del hijo o de la madre- tomaría nota de la duda que se ha producido en su escucha y no tendría prisa por preguntar al paciente a qué deseo se está refiriendo... Quiero decir: no le interesaría tanto precisar, como elemento clave, qué sentido le da el paciente, a fin de comprender qué dice, cuanto captar qué es lo que él ha creído escuchar en ese momento de vacilación del sentido. Intenta captar qué circula entre su paciente y él en relación al deseo... de la madre. Y, a partir de esa madre de la que parece hablar el paciente, buscará qué de lo materno es lo que se ha activado en ese momento de vacilación. Y ello lo hará atendiendo a las resonancias -sonoras, visuales, táctiles, incluso-de unas palabras con otras, y de palabras con gestos, con comportamientos, con sueños, con síntomas...

6 Ver Kristeva, J. y otros, (El) Trabajo de la metáfora, Barcelona, Gedisa, 1985, pp. 43-79 
til.) Con ello estamos diciendo que los significados habituales que surgen en nosotros ante la presencia de los dos términos que componen la metáfora, son impulsados a su borrado, y, así, se crea un "espacio metafórico" al que "acuden" los dos términos creándose un significado nuevo. Al aproximar los significantes "concavidad" y "silencio", ambos quedan en suspenso, y eso hace posible que surja una concavidad otra y un silencio otro, los que acaba de crear la metáfora, una concavidad de silencio. El silencio, nos dice, es, en el orden del lenguaje, cualidad de la concavidad, califica a la concavidad, le pertenece, es el silencio propio, específico, de esta concavidad, el que sólo se produce en esta concavidad... Y que se produce ahora, en este "tiempo de la palabra", tiempo "otro" en el que la palabra, desprendida de sus significados habituales, vuelve a nacer en su singularidad temporal, vuelve a producirse ese instante único en el que la metáfora arranca al significante de ese plácido dormitar en la envoltura del significado y lo sitúa en un tiempo específico, vuelve a confrontarlo con lo enigmático de lo real, lo que todavía no tiene nombre, y lo nombra. Y, así, "eso" sin nombre es ya "realidad", tiene nombre, ha sido sacado del silencio, de la concavidad del silencio... Pues el silencio, viene a decirnos $\mathrm{RG}$, es una concavidad, un marco, un lecho, en donde las palabras, esconden lo más recóndito suyo hasta que la metáfora se lo arranca... Eso sería, para RG, entrar en la concavidad de silencio que es el arte, entrar en el espacio-tiempo mítico hacia el que el artista orienta la mirada del contemplador cuando crea su obra. Y a ese espacio-tiempo mítico remite el analista al paciente, con sus palabras, en la escucha que ambos van poniendo en acto en ese peculiar intercambio de palabras, silencios y gestos que se va produciendo en la sesión. Cuando el paciente emplea las palabras y las refiere sistemáticamente a sus significados habituales, el analista las despoja de esos significados y las remite a esa "concavidad de silencio" en el que, en cierto modo, vuelven a nacer...

\section{El término "concavidad" en los textos de Ramón Gaya}

En el Homenaje a Velázquez (1945), uno de sus primeros textos, presenta RG su propia posición respecto al arte: "Al acercarme a Velázquez he tenido que apartar y quitar de encima de su obra, no un tópico, sino muchos, ya que nunca se falseó y obstaculizó una gran verdad con verdades tan pequeñas, verdades tan míseras, verdades tan mezquinas. (OC, p. 52) "Porque el mundo, la vida del mundo, lo que hace con el hombre no es, como se piensa, revelarlo y realizarlo, sino taparlo, taparlo hasta destruirlo; ella, la vida, lo que quiere es vivir, aunque sea, naturalmente, a costa del hombre, y por eso lo utiliza -engañándole con unas cuantas pasiones hermosas o tristes- hasta convertirlo en leña, en leña para ella, en alimento suyo". "(El arte) nos deja, sin duda, unos cuerpos, unos cuerpos que los historiadores toma- 
ron por el arte mismo, y que son, en realidad, lugares únicamente, lugares casi santos -serían santos si el arte fuese divino, pero no lo es-, lugares donde el arte estuvo, y en los que ahora sólo vemos una como puerta entreabierta, rendija al vacío, que nos llama. Porque el arte no es, como se pensó, una corporeidad, sino una concavidad”. (cursivas mías) (Ibidem, pp. 57-58, 60)

La última frase, en donde se condensa todo el artículo (y, quizá, también todo el pensamiento de RG sobre el arte), es contundente. Frente a la acción de la "vida del mundo" sobre el hombre, tendente a destruirlo, a hacerle incapaz de desprenderse de lo obvio - creer que la corporeidad es lo propio de toda obra artística-, es necesario decir lo que verdaderamente es el arte: una concavidad. Resume así, en un texto marcadamente autobiográfico, su testimonio acerca de cómo él vivió este proceso de vaciamiento de todo aquello engañoso que una cierta cultura había ido acumulando sobre la obra de Velázquez. Él también, al acercarse al pintor sevillano, tuvo que reaccionar frente a la amenaza voraz e insaciable de ser destruido, devorado ("convertido en leña", en "alimento"), y acercarse al arte verdadero, "el arte que toma al hombre en su mano y lo devuelve siempre, desde no importa qué cultura, a su desnudez de hombre", pues no es posible vivir "sin sitio para el hombre, sin vacío, sin el vacío que necesita el hombre para cobijarse y sentirse." (Ibidem, pp. 52). Estar construyendo continuamente ese vacío, esa concavidad, que ofrece el arte, es necesario para sobrevivir ante la amenaza constante de la "vida del mundo".

Retengamos las imágenes. Aparecen ante nosotros figuras destructivas, insaciables, que intentan devorarnos, eliminarnos. Frente a ellas, la imagen contraria: el arte que nos "toma en la mano", y nos lleva a la autenticidad, a la "desnudez de hombre", a la vida verdadera. ¿Cómo no pensar en las imágenes más primitivas que configuran el comienzo de la vida psíquica, en las que, alrededor de los seres que nos reciben en el mundo, nuestros padres -o los que cumplen las funciones parentales-, se van anudando los sentimientos más intensos y contradictorios, como temor, odio, angustia, amor...? Imágenes primitivas que "vuelven", como metáforas, y metáforas que arrastran consigo los afectos más intensos, cuando el hombre se enfrenta al acto "creador". Esa labor del acto creativo conlleva necesariamente la de vaciamiento de uno mismo. Y es esa imagen de uno mismo en el estado de vaciamiento la que se proyecta hacia fuera, sobre el objeto artístico, y "vaciándolo" le otorga un lugar, el lugar del vacío, la concavidad. La obra de arte será tal cuando consiga ser, ella misma, "rendija al vacío", generar en nosotros ese lugar de vacío, cuando no remita a sí misma, cuando sólo ofrezca a quien la contempla la imagen de la propia desnudez. Y ese vacío, añade RG, "nos llama", no es algo indiferente a nosotros, algo de lo que podríamos prescindir; todo lo contrario algo que nos convoca a estar en ese lugar y, así, poder llegar a ser lo que somos.

En este Homenaje a Velázquez, que bien podríamos denominar texto fundacional, condensa RG no sólo su propia posición frente a los juicios que se han vertido sobre Velázquez, sino, también, como vemos, una bien definida "teoría del arte". 
Pero el análisis se irá enriqueciendo en textos posteriores. Seis años después, en El silencio del arte (1951), sin referirse explícitamente a la concavidad, sí nos habla de un "lugar" hacia el que nos sentimos atraídos. "El arte (...) nos lleva, nos arrastra siempre hacia una oscuridad, hacia una oscuridad divina" (Ibídem, p. 69). Estaríamos, pues, arrastrados hacia esa oscuridad y quedaríamos dentro de ese ámbito, de ese espacio que RG califica de "divino". El concepto de "oscuridad divina" será matizado posteriormente en Naturalidad del arte y artificialidad de la crítica $(1975,1996)$. Se distingue aquí entre el "don divino" (que llega siempre "de arriba") y el "don religioso", identificado con el "impulso religioso". Si bien el arte no es religión, sí procede, como ésta, del mismo lugar. "El arte no es religión, pero nos llega de ese mismo lugar, profundo y oscuro como un pozo, del cual nos llega la religión -no lo divino, puesto que lo divino nos llega siempre de arriba-; el arte viene de donde viene el impulso religioso, el don religioso, es decir, la sed; el arte creador nos llega de muy lejos y de muy abajo, como de un abismo, pero no un abismo de caer en él; de allí debió venir también la filosofía: otra hermana, otra agua". (Ibidem, pp. 936-37)

Tendríamos, por tanto, una contraposición entre dos "lugares": "arriba", de donde viene el don divino, y "abajo", de donde vienen la religión, el arte y, posiblemente, la filosofía. La descripción de este último "lugar de origen" - descrito como lugar muy lejano, muy profundo, como un pozo, como un abismo, pero no un abismo que atrae a la caída- hace pensar en la metáfora clásica de la vida pulsional que sitúa la vida pulsional como una "exterioridad" situada "abajo" respecto a un "centro", el yo. ${ }^{7}$

En Velázquez, pájaro solitario $(1963,1967)$, texto fundamental en el conjunto de la escritura gayesca, vuelve a aparecer la noción de concavidad referida ahora a dos obras concretas: la Victoria del Louvre y Las Meninas. "La Victoria del Louvre, por el contrario, aunque empezara por querer ser una escultura inmortal y magistral como tantas otras, pronto ha de librarse de este estrecho compromiso, irrumpiendo francamente en la vida; pronto ha de convertirse, no sólo ya en una criatura más de Dios, sino incluso en una gran concavidad natural (cursivas mías), en un espacio inmenso de naturaleza viviente, con su aire marino, con su cambiante luz tornasolada, con sus nubes imprevisibles en torno". (Ibidem, pp. 105-06)

\footnotetext{
7 Se trata de "espacios metafóricos" (más adelante hablaré de "visualizaciones") utilizados por los creadores: recuérdese la caverna platónica o las descripciones del infierno, purgatorio y cielo de Dante. Freud utilizó estas imágenes, incluso las dejó dibujadas, para describir las llamadas "tópicas". Significativamente, la segunda tópica describe el "aparato psíquico" en forma de un círculo en cuyo interior se distribuyen las tres instancias: ello, yo y superyo. En "El yo y el ello" (1923), las tres instancias quedan encerradas en el círculo; años más tarde, en la Conferencia $31^{\mathrm{a}}$, (1933) introduce una apertura, en la parte inferior del círculo, que ofrece "salida" a una exterioridad, el organismo. Lacan, en sus últimos años, recurrió sistemáticamente a "figuras topológicas".
} 
Llama la atención cómo la obra trasciende pronto la intencionalidad del creador ("querer ser una escultura inmortal y magistral como tantas otras") y, en esta nueva condición, como "criatura de Dios", sin perder su forma escultórica (escultura de bulto representando a una mujer alada, vestida con túnica y manto llevados por el viento y cuyas bellas formas quedan resaltadas por el efecto de "ropa pegada"), pasa a ser "una gran concavidad natural", situada "en un espacio inmenso de naturaleza viviente", como si ella lo generase... Tal forma de percepción artística hace presente lo que pudo haber sido la intencionalidad del autor: que la escultura pudiera inspirar a las que, como mascarón de proa, presidieran la proa de alguna nave y, desde allí, atrajeran las miradas de los marineros. La escultura ya no es tanto lo que se muestra a los ojos, sino lo que, mostrándose -resplandeciente en su hermosura, viva, expuesta a las variaciones de luz y a la imprevisibilidad de las nubes- sugiere, como concavidad, a la imaginación...

Veamos cómo aparece la noción de concavidad en un comentario sobre Las Meninas: "Es cierto que la realidad acude sin falta a la cita de la obra velazqueña, y que incluso parece aposentarse en esa obra, en el recinto vacio, cóncavo, de esa obra (cursiva mía), pero muy pronto comprenderemos que sólo está en ella de paso, de tránsito. La realidad en los lienzos de Velázquez aparece siempre yéndose; yéndose por el fondo, por la puerta del fondo, una puerta que, a veces, como sucede en Las Meninas, es visible, y otras no, pero siempre practicable". (Ibídem, p. 115) La concavidad -en este caso, "la obra velazqueña"-es, pues, el lugar, "recinto vacío", adonde "acude", sin falta, la realidad. Y donde se produce un cierto espejismo: creer que la realidad queda ahí, alojada, aposentada en la concavidad, cuando, en realidad, está sólo de paso, pues su condición es la fugacidad.

Se ha ido perfilando así una noción de "concavidad" a partir de la cual va elaborando RG su propia concepción del arte. La verdadera obra de arte debería poder "sustraerse" ante nuestros ojos, "borrarse", para mostrarnos así la realidad, a la que retiene por breve tiempo y, luego, deja ir, mostrando así su íntima esencial temporalidad. Mostrando así la realidad que somos...

En El sentimiento de la pintura, 1959, hablando de la pintura de Tiziano, dice: "El color, aquí, no parece haber sido aplicado sobre la tela, sino provocado; parece surgido, salido de ese fondo de pozo, de esa concavidad oscura, desconocida, que es, en principio, el cuadro. (cursiva mía). Porque para él (...) el cuadro no será jamás -como viene siendo para los simples pintores, sobre todo después de Cezanne- una pobre "superficie", sino una cueva, una cueva de la que, sin duda, hay que salvar, sacar al exterior, a la luz, toda la vida encerrada allí o allí cobijada". (Ibidem, pp. 41-42) Aquella concavidad, nombrada hasta ahora en abstracto, es ahora "una cueva", "un pozo", en cuyo fondo se aloja algo muy preciado, el cuadro, en contraposición a lo que pueden pensar "los simples pintores", para quienes el cuadro es una "pobre superficie". Podría decirse que toda la vida y la obra de RG 
es el esfuerzo -sacrificio y goce, como veremos- por penetrar en esa oscura concavidad e intentar extraer de ella algo de lo que esconde en su interior.

En este esfuerzo continuado a lo largo de su vida pueden marcarse unos hitos, correspondientes a tres etapas de la vida que él mismo ha ido describiendo: infancia, adolescencia y edad madura. Hitos que jalonan una evolución y, sobre todo, momentos estructurales de un proceso psíquico.

\section{El "itinerario" del proceso creador}

El camino que emprende RG no le va a llevar a una mera concepción del arte, sino a algo de otro orden: lo que denomina su propia "fe en el arte". No se trata, pues, de "gusto" por el arte, ni de "pensamiento" sobre el mismo, sino de una búsqueda azarosa, una quête, en la que va avanzando con incertidumbre, fruición, temor, esperanza, angustia...

Ese camino está marcado, a mi juicio, por tres hitos bien diferenciados: infancia, adolescencia y edad adulta. Pero, ya desde el Homenaje a Velázquez (1945), iremos viendo, cómo esos tiempos - descritos a partir de las tres etapas evolutivas-, trascienden los límites concretos de cada etapa y pueden ser considerados como tiempos lógicos, paradigmas del proceso creativo.

La infancia: la percepción del conflicto entre la propia vida pulsional y la voz paterna

"De mis primeros años de preocupación y vocación por la pintura, sólo guarda mi memoria una triste antipatía por Velázquez, frialdad, respetuoso despego. Acaso influyó mucho en ese desvío la voz paterna. Niño aún, oí decir a mi padre que el arte supremo no era sino aquél que lograba emocionar nuestros corazones. Ante una reproducción de Las hilanderas no conseguí escuchar en mí mismo palpitación alguna; en cambio, ante el carácter y el misterio visible de Goya, ante la picardía de Las majas o la desgarradura de Los fusilamientos se me entrecortaba la respiración”. (Ibidem, p. 54)

Hay, pues, un primer tiempo, el de la infancia, en el que se recuerda a sí mismo viviendo la contradicción en que le sitúa la "voz paterna", que le induce a estimar que sólo es arte, "arte supremo", el que consigue emocionar. Hay una cierta "teoría de las emociones" según la cual éstas nacerían como consecuencia del encuentro perceptivo del sujeto con el objeto artístico y serían ellas las garantes del arte supremo.

Ahora bien, en el recuerdo infantil lo que se subraya es precisamente el conflicto ante la imposición de la voz paterna -vivida como instancia superyoica-cuando las emociones que "deberían" haberle suscitado ciertas obras de arte-aquéllas que el padre consideraba como "arte supremo"- no correspondían en nada con lo que 
verdaderamente se suscitaba en él: Velázquez no le hace sentir nada (ante Las Hilanderas); sin embargo, Goya le abre al misterio de la vida pulsional, tanto en su vertiente erótica (la excitación sexual que le produce la contemplación de Las majas), como en su vertiente tanática (el desgarramiento psíquico que le afectaba al aparato respiratorio, ante Los fusilamientos).

Sólo en la medida en que el niño puede ir viviendo ese conflicto resultará posible "romper" con el dictamen paterno y, así, discriminar sus propios afectos respecto a la normativa que le viene de fuera. Irá, así, estructurando el propio psiquismo y capacitándose para la entrada en la pubertad y adolescencia. De ello nos advierte Freud en La novela familiar del neurótico (1909/2001, p. 217): "En el individuo que crece, su desasimiento de la autoridad parental es una de las operaciones más necesarias, pero también más dolorosas, del desarrollo. Es absolutamente necesario que se cumpla, y es lícito suponer que todo hombre devenido normal lo ha llevado a cabo en cierta medida. Más todavía: el progreso de la sociedad descansa, todo él, en esa oposición entre ambas generaciones".

\section{La adolescencia: el poder fascinador de la belleza}

Veamos cómo recuerda RG esta etapa: "Más tarde, ya un adolescente, con la ayuda de algo que leí por entonces, supuse que el arte no era expresividad, sino belleza. Y no, no es esto tampoco. Ignoraba, pues, la existencia fría, fija, pura, del alma, del alma sola, del alma que es el arte, del alma de donde brota el arte, y adonde vuelve, después de una sucia materialización, de un desdichado paso por la tierra, como a su pozo único. Ya nunca más ha de salir de esa especie de encierro propio; y no espera gloria, ni amor, ni justicia. De tan inhumana que es, vive al margen también de lo divino". (Ibidem, p. 55)

Como que hubiera resultado en vano su esfuerzo infantil por acallar la voz paterna y su búsqueda adolescente, en la lectura, de otras figuras aptas como sustentadores del saber sobre el arte. Llega entonces a un estado de ignorancia, en el que, a lo más, según consigna él mismo, cabe sólo la suposición, no la certeza, de que el arte no es expresividad (se entiende, de los afectos, tal como el padre había intentado transmitirle), sino belleza... Pero, cuando leemos estas líneas tenemos la impresión de que se hubieran reactivado en el autor, en este momento evocador de su propia adolescencia, las suposiciones de entonces y reaccionase con toda energía. No. El arte no es belleza, afirma ahora. Y nos expresa lo difícil que es llegar a esta conclusión en lo álgido del despertar de la sexualidad adolescente. ¿Cómo comprender el cuadro que dibuja ante nosotros? Se trata, nos dice, del "alma del arte" que va buscando "esa especie de encierro propio", hasta que lo encuentra, si bien "después de una sucia materialización, de un desdichado paso por la tierra". Pozo, encierro... figuras de la concavidad, teñidas ahora de connotaciones negativas: suciedad y desdicha. ¡Qué contraste con la fascinación por la belleza en que 
quedó atrapado en la adolescencia! Pero entonces. ¿Qué es la belleza? ¿Es posible responder a esta pregunta cuando sabemos que en la adolescencia el objeto queda investido con tanta intensidad por el propio deseo? "No es empresa fácil, pues se trata, nada menos, que de pasar de la adolescencia a la madurez que es la creación (...) Pero el adulto real y verdadero, como el creador predestinado, sienten muy bien que necesitan irse, renunciar, sobrepasar; irse de algo, de algo precioso, valioso; renunciar a algo muy suyo; sobrepasar algo que enamora, que aprisiona (...)" (Ibidem, p. 108). Textos que también podemos leerlos como referidos al pasaje que va de la infancia a la adolescencia, pues el encuentro con la belleza en la adolescencia arrastraba todavía los ecos de la voz paterna. Ecos que le dicen de la "verdad" de su propia vida emocional como criterio orientativo en la apreciación de la obra de arte... Aparece, pues, tanto en el pasaje a la adolescencia como en el pasaje a la edad adulta, la ambivalencia de sentimientos, asociados a significantes de "suciedad", "desdicha", "algo que enamora, que aprisiona"...

Pero la belleza no es sólo algo que nos aprisiona y de lo que hay que "irse", sino algo que contraría radicalmente el paso a la madurez. Más adelante, en Tropiezo y contrariedad de la belleza (Tramonto romano), en 1976, vuelve RG a estas descripciones de lo que considera etapa adolescente. Y nos muestra cómo la belleza es obstáculo para dejar esta etapa. "(La belleza) es algo, en fin, que sin saber qué, por qué ni cómo, nos corta radicalmente el paso. (...) primero, sí, seremos empujados, invitados a entrar; (...) pero pronto la muy apetitosa y carnosa belleza ha de mostrarse impenetrable, inviolable, dejándonos, de repente, y a una cierta profundidad suya, como detenidos, como interrumpidos, abandonados a una penosísima insatisfacción". (Ibidem, p. 384) "La belleza nos arrastra, diríamos, hacia una orilla extrema, última, de nosotros mismos, y nos deja allí, en ese borde difícil, como desprovistos y desasistidos, sin saber qué hacer, sin tener qué hacer. Porque la belleza nos envuelve siempre en un abrazo demasiado apretado y demasiado grande, es decir, en un abrazo que nos ahoga, que nos sofoca, que nos inutiliza, que nos... castra. (...) No nos queda más, entonces, que... irnos de la belleza -irnos de ella y de ese sitio suyo, insondable, en que está siempre-, irnos, y más que tristes, como contrariados, mortificados". (Ibidem, p. 386-87)

Una primera fase de desconcierto, de desorientación, "algo, en fin, que sin saber qué, por qué ni cómo, nos corta radicalmente el paso". El adolescente no sabe qué es lo que le corta el paso, pero sí percibe, de pronto, como una iluminación, que el paso se le ha cortado... Difícilmente podríamos encontrar entre los textos psicoanalíticos una descripción más acertada del movimiento de seducción en el que el sujeto, fascinado por la belleza, queda atrapado en ella y se encuentra con lo real de la castración. Es el lado oscuro de la belleza: sin darnos cuenta, quedamos colocados en ese lugar límite de la percepción de la propia castración. El adolescente se hace consciente de que no puede dejarse llevar por los halagos de la belleza. Está 
actuando la fuerza estructurante de la represión, que le lleva a poner en acto la proyección del propio deseo de incorporar el objeto-belleza. La percepción consciente del objeto-belleza, mostrándose como "muy apetitosa y carnosa belleza" $\mathrm{y}$, al mismo tiempo, como "impenetrable, inviolable", soslaya la percepción, a nivel más inconsciente, del propio deseo de incorporar el objeto -deseo oral, devorador- y deseo de penetración. La angustia de castración oscurece la percepción del propio deseo y vehicula la proyección del mismo en el objeto-belleza. Será necesario vislumbrar esta marejada de conflictos pulsionales a partir de aquellas sensaciones, sentimientos y fantasías que afloran a la conciencia, tales como la sensación de estar "como detenidos, como interrumpidos, abandonados a una penosísima insatisfacción", y esperar así que la belleza "se retire"; es decir, que se vayan apagando los sentimientos asociados a las pulsiones en conflicto. Coloca RG en el objeto-belleza, el "retirarse" del adolescente de su propio deseo incestuoso.

En el Homenaje a Velázquez hablará de un límite entre la belleza y la nada: "Pero lo bello es, sin duda, el muro donde acaba la vida y donde empieza, no la muerte -porque la muerte está viva también- sino la nada. Sentimos que detrás de la belleza no hay nada, que todo cuanto puede ofrecernos termina en esa como pared que nos presenta siempre; termina en ese tope con que nos sale al paso, dejándonos fuera de ella, puesto que ella, todo lo que es ella, está en lo exterior de sí misma. Creemos que la belleza nos emociona, que nos habla, pero no es verdad; lo que sucede es que nos asusta, nos asusta precisamente su silencio, lo que tiene de silencio final, de final visible. La belleza es, pues, como máscara de la nada, un disfraz de la nada". (cursiva mía). (Ibidem, p. 57)

Entendemos ahora mejor cómo la metáfora "concavidad de silencio" encierra en sí misma el intenso dramatismo de la larga quête que RG ha transitado para llegar a esta concepción del arte. En ese camino la identificación del arte con la belleza era un verdadero escollo, una "contrariedad", un canto de sirena que habrá de escuchar siempre el navegante que ha emprendido ese viaje... La propia pulsión incestuosa estará siempre, como contrariedad, en el camino hacia la madurez de la vida sexual. Y ello es posible en la medida en que la belleza, significante privilegiado en la adolescencia de la propia pulsión sexual, es percibida en sus propios límites.

Pues la belleza -que tanta fascinación ejerce durante la adolescencia- es sólo un límite, un "muro", una "pared", un "tope" entre la vida y la nada. "Sentimos que detrás de la belleza no hay nada". Ahí, en ese límite, termina. Y desde ahí nos sale al paso haciéndonos creer que es algo más. En realidad, es pura exterioridad. "Creemos que la belleza nos emociona", afirma, aludiendo a ese adolescente sentir la belleza, y aludiendo también a aquel recuerdo infantil en el que, según el padre, las emociones nos garantizaban dónde estaba el arte supremo... "Pero no es verdad". La emoción que provoca en nosotros no es la que creemos que es; la belleza, en realidad, nos asusta, pues nos hace presentir, detrás de ella, su silencio final. 
Ese "silencio final" es el que verdaderamente nos aterra, pues es evocador de la desaparición de la vida pulsional, lo que RG denomina "la nada". La belleza se interpone entre nosotros y ese abismo y nos detiene ahí. El espejismo -que RG califica como "adolescente"- consiste en hacernos creer que es ella la que está al final, sin remitirnos a nada más que a ella... Entendemos ahora mejor cómo la metáfora con la que define al arte, "una concavidad de silencio", es metáfora -casi diríamos "necesaria"- para poder despojar a la belleza del carácter engañoso de corporeidad. La metáfora empleada por RG despoja del todo a la belleza, la desnuda, la muestra en su desnudez absoluta, en su negativo -la concavidad-y la remite a ese silencio final como elemento intrínseco a la vida pulsional. Somos un entramado de pulsiones y en tal entramado el silencio, posible significante de la pulsión tanática, es elemento esencial, que no puede ser negado. Así, pues, en contraposición a esta belleza adolescente, la belleza auténtica es la que se presenta ante nosotros, atrae nuestra mirada y cuando ésta ya la contempla, se retira y deja nuestros ojos mirando a ese vacío que ella crea en su retirada... Más: hacia la que ella orienta nuestra mirada.

\section{La madurez: la belleza como apertura al vacio}

Es, quizá, en el Diario de un pintor (1952-1953) donde encontramos los textos más significativos en la descripción de lo que significa para el artista la superación de la "concepción adolescente" del arte. Se nos abre ahora, al retirarse la auténtica belleza, un paisaje de abismos -con riesgo de vértigo y de caída-, "una santa zona de demencia" que el artista debe atravesar. Imágenes que se abren a su mirada más allá del límite que dibujaba la concavidad... La tentación será intentar volver al espejismo adolescente, el que nos lleva a creer que el arte es una corporeidad, cuando, en realidad, la verdadera obra de arte es la que deja ver "una como puerta entreabierta, rendija al vacío, que nos llama”.

Surgirá entonces la creación, la verdadera creación. En Venecia, el 24 de enero de 1953, escribe: "El pensamiento -todo pensamiento legítimo, vivo- ha de pasar inevitablemente por un estado, diríase, de... demencia, y desembocar después -si se trata de un pensamiento valioso y vigoroso-, no en la cordura, en la simple y tonta cordura, sino en la... sabiduría, es decir, en esa locura superada que viene a ser la sabiduría, o... la verdad, la posible verdad. (Lo malo es cuando incluso el pensamiento verdadero no logra, por algún motivo, cruzar, atravesar ese peligroso espacio de locura, superar esa difícil prueba de la locura, ya que entonces naufraga sin remedio en el disparate.) No, no hay pensamiento auténtico, real y verdadero, sin esa obligada y santa zona de demencia: es como una marca suya de legitimidad; todo supuesto pensamiento que no sufre y pasa esa prueba, no es pensamiento, sino mero razonamiento, o reflexión, o... idea, pero no pensamiento".. (Ibidem, 431-32). Y pocos días más tarde, el 18 de febrero: "Toda obra suprema parece estar asomada a una especie de... abismo. Incluso la de Velázquez - tan firme, tan segura, tan... 
justa- parece estar al borde de algo sin fondo, sin fin, que no acaba, que no concluye" (Ibidem, p. 438-39)

Veámoslo. En Naturalidad del arte y artificialidad de la crítica $(1975,1996)$ : "No, no se trata de una tarea, ni se trata de una aportación, ni se trata de un servicio que el artista presta gustoso, generoso, a la sociedad, sino más bien de una especie de... sacrificio, un sacrificio que se cumple, diríase, en el propio seno, en el propio regazo de la naturaleza, en la viva concavidad sagrada de la naturaleza (cursivas mías), es decir, antes y fuera de toda noción o sombra de sociedad, de "civiltà", de cultura. (Ibidem, pp. 935-36)

La concavidad de silencio adquiere ahora rasgos maternales. Aparece como formando parte de la naturaleza, su "seno", su "regazo", y dotada de carácter "sagrado". Es, pues, un centro sagrado, un lugar de fruición íntima. En El sentimiento de la pintura (1959), refiriéndose a la llamada "escuela veneciana" nos explica el hallazgo que realizó al descubrir cómo "lo veneciano" no es sino "una reaparición de lo pictórico perenne, de lo pictórico original, del pecado original de lo pictórico", y la repercusión afectiva que dejó en él tal hallazgo: "Estaba casi alegre. Me parecía haber topado, al fin, con el manantial antiguo, femenino, tibio, húmedo, materno, de la pintura; un manantial (...) (Ibidem, p. 39) $\mathrm{Y}$ en sus Retales de un diario (1956-1963), en Roma, 10 de febrero de 1963, comenta: "Velázquez recibe la pintura a cuerpo limpio. a torso limpio, pero no con ese tanto de desafío que hay en el torso del hombre, sino como un regazo, como un regazo materno (cursiva mía)". (Ibidem, 511)

Tal visión puede referirla, con naturalidad, a la persona de Velázquez. En el Homenaje a Velázquez, 1945: "Hoy, a este portugués tan andaluz, me parece verlo ya directamente, y ha llegado a ser, para mí, como un centro exacto de todo. Mi fija pasión, o mejor dicho, mi compenetración absoluta con la obra, el silencio, el gesto, el ademán de Velázquez, es ya tan involuntaria, casi tan secreta que muchas veces hasta la olvido". (Ibidem, p. 52)

En otros momentos no es la concavidad la que es descrita con rasgos maternales, sino el espacio que se abre a la contemplación cuando la concavidad se rasga... $\mathrm{Y}$, así, nos da la clave de la atracción que ejerce ese vacío sobre el artista. Éste, recordemos, es invitado a asomarse, y, al hacerlo, -en esta descripción de paisajes imaginarios que estamos realizando- encontrará... la naturaleza, "el propio regazo de la naturaleza".

Volvamos a la cita con la que comenzábamos estas reflexiones. Nos decía RG que el arte, en realidad, nos había dejado, a lo largo del tiempo, unos lugares "donde el arte estuvo, y en los que ahora sólo vemos una como puerta entreabierta, rendija al vacio, que nos llama. Porque el arte no es, como se pensó, una corporeidad, sino una concavidad". (cursivas mías) (Ibidem, p. 60)

Recapitulemos. Lo que caracteriza al artista adulto, según RG, es haber llegado a la conciencia de lo que verdaderamente es el arte: una apertura al vacío, una con- 
cavidad que se rasga y "abre una rendija al vacío". Aparecen imágenes tales como "abismo", posible "caida", "naufragio", "peligroso espacio de locura que el pensamiento puede no conseguir cruzar". Ante esa visión el verdadero artista no se amedranta, sino, todo lo contrario, se arriesga a transitar ese espacio, alentado por la idea de una "especie de... sacrificio", pues sabe -ahí está la creencia en el arte- que tal sacrificio se cumple "en el propio regazo de la naturaleza, en la viva concavidad sagrada de la naturaleza".

\section{Resonancias}

¿Cómo no escuchar en estos textos las resonancias de algunas tradiciones, especialmente las que se han acuñado en Oriente o han encontrado allí su inspiración? Pienso, entre las más cercanas a nosotros, en las descripciones del propio proceso interior que han hecho María Zambrano y San Juan de la Cruz. Ya hemos visto cómo en la metáfora del arte como "una concavidad de silencio" se condensa no sólo lo que es el arte, sino también cuál es el proceso que debe recorrer el verdadero artista. La metáfora cumple esa función de condensación de todo el proceso creador, pero en ella el elemento dinámico, el camino haciéndose día a día, no aparece explícitamente, es necesario hacerlo "resonar" en la escucha. Tiende, así, la metáfora, en su intento de evocar lo esencial, a adquirir el carácter de una "visualización", como un mapa en el que se dibujara el camino realizado. Y surge, en la dialéctica entre lo consciente y lo inconsciente, poniendo en juego los recursos del discurso, en la conciencia de los límites del mismo, en un intento de síntesis, de esquematización... En ocasiones, este intento de síntesis, aún a riesgo de incurrir en una cierta estatificación del pensamiento, busca expresividad en algún recurso plástico como el dibujo. (En este caso, según sea el nivel de abstracción se requerirá un mayor o menor recurso a la apoyatura de la palabra. Pensemos en ciertas obras de arte abstracto: la percepción que hoy tenemos de este arte está acompañada de los variados discursos que han surgido alrededor del mismo.)

Intentaré mostrar cómo, a partir de la imagen de la concavidad, llega RG a visualizaciones muy cercanas a las que encontramos en María Zambrano y San Juan de la Cruz.

En Claros del bosque, habla María Zambrano (1977, p. 53) sobre el vacío y la belleza: "La belleza hace el vacío -lo crea-, tal como si esa faz que todo adquiere cuando está bañado por ella viniera desde una lejana nada y a ella hubiere de volver, dejando la ceniza de su rostro a la condición terrestre, a ese ser que de la belleza participa. Y que le pide siempre un cuerpo, su trasunto, del que por una especie de misericordia le deja a veces el rastro: polvo o ceniza. Y en vez de la nada, un vacío cualitativo, sellado y puro a la vez, sombra de la faz de la belleza cuando parte. Mas la belleza que crea ese su vacío, lo hace suyo luego, pues que le perte- 
nece, es su aureola, su espacio sacro donde queda intangible. (...) Y en el umbral mismo del vacío que crea la belleza, el ser terrestre, corporal y existente, se rinde; rinde su pretensión de ser por separado y aun la de ser él, él mismo; entrega sus sentidos que se hacen unos con el alma. Un suceso al que se ha llamado contemplación y olvido de todo cuidado".

¿Cómo comprender esa afirmación tan rotunda "la belleza hace el vacío -lo crea-"? Desglosemos el párrafo. Trata de explicarnos María Zambrano qué entiende por "contemplación y olvido de todo cuidado" y para ello nos describe una peculiar visualización. Se trata de un "suceso", un acontecimiento, en el que el "ser terrestre" percibe, a la vez, su entorno -bañado, en su faz, por la belleza- y a sí mismo en íntima unión con ese entorno. Esa percepción de sí mismo y del entorno se realizaría en un lugar preciso, el "umbral del vacío", desde donde percibe también que ese llegar a él de la belleza provendría de un movimiento cíclico que se origina "desde una lejana nada", y vuelve hacia él una y otra vez. Y que, en cada vuelta, la belleza "le pide siempre un cuerpo", y ella, a su vez, le entrega "la ceniza de su rostro": eso sería la participación del ser terrestre en la belleza, a eso "se rinde", se entrega del todo, en cuerpo y alma, "entrega sus sentidos que se hacen unos con el alma", pues se ha olvidado de sí, sobre todo, de la pretensión (añadiríamos, narcisista) de "ser él" -ser "por separado"-

Cuando María Zambrano afirma que la belleza "crea" el vacío, nos dice, a mi juicio, que la belleza es un lugar límite, desde donde se le ofrece al ser terrestre la única perspectiva de que dispone para esa visión del mundo y de sí mismo. Es desde ahí donde la belleza aparece como "creadora" del vacío, pues de éste no se me ofrece ninguna percepción. Decir que la belleza "crea" el vacío equivale a decir que, desde nuestra perspectiva, "señala" la dirección donde intuimos el umbral del vacío, dibuja una línea separadora entre un más acá, que se constituye como ámbito precisamente por esa línea, y un más allá, el vacío. El ser humano, "terrestre, corporal, existente", se rinde, pues, no ante la belleza, sino ante esa realidad que trasciende a la belleza y que ésta, en tanto lugar-límite, le está señalando -el vacío, la nada-, un lugar de donde ella viene y adonde va, y de donde, en cada una de las vueltas, cuando llega acá le demanda su cuerpo y le trae... la ceniza, es decir, un resto de cómo ha ardido allá.

Visualización, la de María Zambrano, coincidente en gran parte con la que hemos analizado en RG. En ambos la aproximación conceptual a la belleza requiere de esta especie de "cosmovisión" -que se despliega ante el creador/contemplador- donde muestra lo que es, la $f a z$-diríamos, amable- ante la que "se rinde" el ser humano, en Zambrano, a la que se "sacrifica", en RG. Pero en la filósofa encontramos mejor definida la que podríamos denominar "dinámica de la belleza", ese continuo vaivén desde el vacío y hacia el vacío, requiriendo y entregando la "ceniza”. En RG la belleza, límite también, línea separadora de una concavidad y algo 
que la contiene, consiste en hacernos ver la concavidad rasgada, y vislumbrar, tras ella, a su través, la nada...

Esa capacidad de irrumpir en un espacio, rasgarlo, la trabaja María Zambrano cuando recurre a la metáfora de la luz del amanecer, especialmente en los fenómenos del alba y la aurora. Clara Janés (2010, pp. 114-115), que ha analizado detenidamente estos textos de su maestra y amiga, y ha sabido precisar en ellos las referencias a San Juan de la Cruz, señala, comentando Claros del bosque y De la Aurora, cómo irrumpe la luz del alba al final de la noche, la rasga, como luego también la luz de la aurora. Cita, en primer lugar, los comentarios del santo a su propio verso "en par de los levantes de la aurora": "Así como los levantes de la mañana despiden la oscuridad de la noche y descubren la luz del día, así este espíritu sosegado y quieto en Dios es levantado de la tiniebla del conocimiento natural a la luz matutinal del conocimiento sobrenatural". Y comenta Janés: "Se trata, pues, siempre de un conocimiento que además se eleva de la sombra y aporta luz; nace, por lo tanto, en un marco de oscuridad. (...) La Aurora supone, pues, un despertar y, por ello, un sueño previo necesario. Es el límite entre ambos y se presenta como una raya, "como una línea que separa. (...) El alba comienza a fundirse, casi a huir, ofreciendo levemente la imagen de todo un reino", y es, a su vez, "anunciada por un específico silencio, por un silencio revelador". No sorprende, así, que sea propicia a apariciones: "Por amplias que sean sus alas, la luz auroral que sigue al alba es como un boquete (cursiva mía), un lugar que tiende a absorber y ofrece al par la inminencia de que algo inconcebible aparezca. ¿Un ser? Un animal quizás.”

Volvemos a encontrar la misma idea que visualizó RG con la metáfora de la concavidad rasgada, trasladada ahora a la irrupción de la luz auroral en la oscuridad. La luz es, para María Zambrano, metáfora de la alteridad radical que irrumpe, en un preciso instante, en la vida del sujeto y desborda su capacidad de pensar e imaginar. Tratándose de estas primeras luces del amanecer, se apuntan dos rasgos de esa alteridad: la inminencia de su llegada y el riesgo de ser absorbido, tal como precisaba Janés. El sujeto creador, diríamos, vive ya, en la percepción del propio deseo, que esa alteridad está ya ahí convocándole al riesgo de una unión íntima. La "nada" a la que se refería Zambrano en los párrafos anteriores no aparece ya como algo situado allá, más allá de la concavidad del arte, sino adviniendo al sujeto, constituyéndose éste, podríamos decir, por su relación con esa alteridad.

San Juan de la Cruz, en Llama de amor viva (1964, p. 828), lo expresará a través de una metáfora doble: la de la unión del amado y la amada y la de la llama, metáfora, a su vez, del efecto que ha dejado en la amada el amor del amado.

¡Oh, llama de amor viva, que tiernamente hieres

de mi alma en el más profundo centro! ; 


\author{
pues ya no eres esquiva, \\ acaba ya, si quieres; \\ rompe la tela de este dulce encuentro.
}

Herida, pues, el alma por la llama del amor, desea intensamente que se rompa la tela que separa todavía a los amados. La metáfora no es ya la de una concavidad rasgada, sino la de un "dulce encuentro" entre los amados. Pero es la amada, herida "tiernamente" por esa "llama de amor viva" en su "más profundo centro", metáfora ahora del esposo, a quien expresa su anhelo: acaba ya, si quieres; rompe la tela de este dulce encuentro. El significado sexual de la expresión está presente en el comentario en prosa que hace el santo (Ibidem, p. 849) cuando, refiriéndose a la acción del Espíritu en el alma, dice: "hace él en ella estos embestimientos divinos y gloriosos a manera de encuentros que, como son a fin de purificarla y sacarla de la carne, verdaderamente son encuentros con que siempre penetra" (...) A esa intimidad se está refiriendo RG cuando, al final de Velázquez, pájaro solitario (OC, p.177), en contraposición al sentimiento de estar aprisionado por la belleza, habla del "abrazo absoluto" cuando "(...) la realidad, la realidad completa, sin desmenuzarla ni separarla, ha sido simultáneamente vista y comprendida por él (Velázquez) como "bodegón", como "paisaje" y como "figura", es decir, con atención humildisima, con amoroso despego, con entrañable proximidad. Es así como se produce ese abrazo suyo absoluto".

Pero la cita con la que comenzamos estas reflexiones continúa: "En un momento he podido creer que eso era el arte. (Y lo es, en definitiva)". Como que volviera ahora RG su mirada hacia ese instante feliz en que surgió la metáfora, "concavidad de silencio", volviera a recrearla en su interior, volviera a encontrársela e, inmediatamente, pensara que tal expresión es referible al arte, es el arte. Al principio con duda, con titubeo, situando este titubeo en el pasado, "he creído que eso era el arte", $\mathrm{y}$, enseguida, disuelve la duda y afirma con rotundidad, en presente: "y lo es en definitiva". Así, pues, decir "concavidad de silencio" es decir "arte", si bien se impone una aclaración: "arte" en el sentido que ha dado siempre a esta palabra RG, es decir, el arte verdadero, la vida. De ahí que concluya: "pero una concavidad de silencio es en realidad lo vivo. El arte, si es vivo, participa de esa condición".

Resumo: lo vivo es condición del arte verdadero y este dárseme lo vivo que es el arte, este ofrecérseme el ser del arte -0 , mejor, este ofrecérseme el ser desde el arte verdadero-, no puedo sino vivirlo como una realidad misteriosa que me invita a adentrarme en ella, como una cueva que, desde su interior, desde su silencio me 
invita a entrar dejando fuera las voces que me avisan del peligro, pues esa cueva puede esconder en su interior el abismo... O se me presenta como un inmenso espacio abierto en el que ya estoy, y en el que me siento invitado, simplemente, a permanecer ahí, en silencio, como cuando quedamos extasiados ante la inmensidad del cielo en una noche oscura... O, quizá, alejada la oscuridad, despierte en mí un ansia por ascender hacia lo que, desde allá arriba me solicita...

RG, en Velázquez, pájaro solitario, habla de un "gesto de despego" y es "tan apagadamente "musical", regulado por un tempo tan apacible, que casi no se nota, ni se oye, ni se ve; es como si saliera poco a poco del arte sin sentir; como si se levantara y arrancara del voluptuoso barrizal del arte, no con violencia o decisión heroica a la manera de Miguel Angel o de Tolstoy, sino muy tierna y silenciosamente; como si se fuera de allí -de ese lugar malsano, palúdico, que es el arte-, no escapando por pies, ni siquiera en forma de vuelo, sino por un milagroso acto simple y solemne de ascensión" (Ibidem, p. 108)

San Juan de la Cruz, en sus Dichos de Luz y Amor (1964, p. 967), fue construyendo, a partir de la imagen del pájaro, una metáfora de este ansia específica de vuelo. Metáfora que va borrando -pues ésa es, recordemos, la función esencial de la metáfora- los rasgos de lo que nos ofrece la experiencia y describe un pájaro inexistente. No importa, pues el poeta lo hace existir poéticamente. Se trata de un "pájaro solitario" que no destaca por su color, que vuela a lo más alto, con el pico abierto al aire y que canta suavemente.

Suavemente... Pero con canto que atraviesa los siglos. Y su dulce sonido llegó un día a los oídos de RG. Estaba escribiendo sobre Velázquez. Al escuchar ese canto, brotó la metáfora: Velázquez, pájaro solitario.

\section{Bibliografía}

Freud, S., "El yo y el ello" (1923), en Obras Completas, Vol. XIX, Buenos Aires, Amorrortu Editores, 1971, pp. 1-66

Freud, S., "El malestar en la cultura", (1930), en Obras Completas, Vol. XXI, Buenos Aires, Amorrortu Editores, 1971, pp. 57-140

Freud, S., "Nuevas conferencias de introducción al Psicoanálisis", Conferencia

31: "La descomposición de la personalidad psíquica" (1933), en Obras

Completas, Vol. XX, Buenos Aires, Amorrortu Editores, 1971, pp. 53-74

GaYA, R., Obras completas, Vol. 1, Valencia, Pre-textos, 2010

JANÉs, C., María Zambrano, desde la sombra llameante, Madrid, Siruela, 2010

JuAn de la Cruz, Vida y obras completas de San Juan de la Cruz, Madrid,

Biblioteca de Autores Cristianos, 1964

Kristeva, J. y otros, (El) Trabajo de la metáfora, Barcelona, Gedisa, 1984/1985

LACAN, J., "El tiempo lógico y el aserto de certidumbre anticipada. Un nuevo sofis- 
ma", en Escritos, I, Mexico-Madrid-Buenos Aires, Siglo XXI, 1966/1971, pp. 21-36

Trapiello, A., http://www.cervantesvirtual.com, p.190, Del pintar. Trazado de desnudo 